\title{
The Civil Liability of Suppliers of Services within the European Communities and its Impact on Liability Risk and Insurance
}

\author{
by John Cowell \\ "Ubi emolumentum ibi onus"
}

\section{Preliminary remarks}

This paper is based on the following assumptions:

a) that the completion of the common market within the European Communities requires the progressive harmonisation of public and private law;

b) that the scope of community law will continue to grow in line with developments towards fuller economic, social and political integration within the European Communities;

c) that the trend towards liability independent of the fault of the wrongdoer in private law is now irreversible;

d) that the Roman or continental law tradition will continue to be the major influence on community law in future years;

e) that American influence on western Europe has been grossly exaggerated.

These assumptions may be controversial. Some are taken as read. Others are discussed below.

We do not seek to draw definitive conclusions - merely to set the scene for further research and debate. But we would not wish for one moment to pretend that we do not have a bias in favour of the consumer or that we do not believe that greater emphasis should be placed on the social - as opposed to the commercial - role of liability insurance.

\section{Introduction}

The present political climate in western Europe favours private solutions - private law and private initiatives. This is supported by community law. The Treaty of Rome established the primacy of community law in areas of community competence. Decisions of the European Court of Justice are taken by judges largely formed by continental legal traditions. Continental law, rather than Anglo-Saxon law, will be the major influence on the development of public and private law.

* This paper draws partly on views expressed in a paper delivered at the Irish Centre for Community Law on 1 December 1990 . Views expressed here are personal and do not necessarily represent the views of any company or organisation with which the author may be associated. 
Private law and private initiatives on their own are not enough. They must be backed by effective sanctions. There will always be a place for public law and public initiatives. And this despite current trends towards deregulation or, more correctly, self-regulation.

1992 is a major step towards closer European union. The approximation of laws is a key element in the process of European integration. Civil liability in community states is increasingly influenced by the growth of community law and community jurisprudence. This, in turn, will influence civil law in other European countries which often take up ideas worked out in the European Communities.

"Europe 1992" is essentially about the "establishment and functioning of the internal market" (art. 100a of the Treaty of Rome). After 1992 the common market will become a reality with the abolition of the remaining "restrictions on freedom to provide services" within the European Communities (art. 59). Trade in insurance (whether by way of establishment or by way of transfrontier transaction) is fundamental to this process.

Liability insurance is the poor relation in the otherwise rich family of insurers. Liability exposures are enormous. Liability income is derisory compared to the life or property branches.

Liability insurance is third party insurance. It is concerned with the compensation of damage to third parties (damage to persons other than the policyholder). It is not concerned with the compensation of damage to first parties (damage to the policyholder himself). It is solely concerned with the liability of the policyholder for damage to third parties according to the provisions of private law (civil law). It is variously known in Europe as civil liability insurance, public liability insurance or general liability insurance. In this paper we shall speak of general liability insurance.

Liability of the policyholder according to the provisions of public law (administrative or criminal law) is not insurable under the general liability policy. This is basic to liability insurance throughout western Europe.

\section{Basic references and considerations}

\subsection{European Communities}

The European Coal and Steel Community (ECSC) was set up in 1951 (First Treaty of Paris). The short-lived European Defence Community (EDC) followed in 1952 (Second Treaty of Paris). The European Economic Community (EEC) was set up in 1957 (First Treaty of Rome) and the European Atomic Community (Euratom) in 1958 (Second Treaty of Rome). The councils and the commissions of the three surviving communities were merged on 1 July 1967 into "a Single Council and a Single Commission of the European Communities" (CEC) under the Treaty of Brussels (Merger Treaty) of 8 April 1965. Consumer and environmental questions are dealt with by Directorate General XI.

A single European Court of Justice (ECJ) was set up in 1957 (convention on common institutions of 25 March 1957). In late 1989 a new Court of First Instance came into operation to deal with certain questions previously dealt with by the Court of Justice, e.g. appeals against commission decisions on competition matters.

A single European Parliament has been directly elected since 1970. The powers of the Parliament have been strengthened under the Single European Act of 1986. 
The Communities were conceived as a means of :

- achieving a closer union of the peoples of Europe;

- maintaining peace and creating prosperity;

- trying to make European society more just and humane.

Community policy seeks to achieve these goals.

\subsection{Single European Act}

The Single European Act of 17 February 1986 is arguably one of the most important European developments since the original treaties setting up the European Communities between 1951 and 1957. The act which came into effect on 1 July 1987 (art. 33.2) did two things of immediate interest to insurers and insurance users. First, it provided new impetus to the work of European integration by laying down a timetable for the completion of the common market by 31 December 1992 with the abolition of the remaining internal barriers to the free movement of goods, persons, services and capital within the European Communities (art. 13 of the act and art. $8 \mathrm{a}$ of the revised treaty).

The act advanced the prospect of one insurance market (instead of twelve separate national markets) with a surface area of nearly $2,385,000$ square kilometres, a population of almost 340 millions and an insurance turnover in excess of 200,000 million écus produced by more than 4,000 insurance undertakings).

Freedom to provide insurance services now exists in eight of the twelve member states. Since 1 July 1990 insurers incorporated in any one of the eight states have been free to write marine, aviation and transport risks and most (but not all) large industrial and commercial (including professional) non-life risks in another member state by way of services, that is, by transfrontier transaction subject to "home country" controls and regulations (where "home country" means the country of the insurer providing the service). The supervisory authorities in the remaining four member states are free, of course, to maintain existing prohibitions on non-admitted (non-authorised) insurance.

Meanwhile, the single insurance market for industrial and commercial risks will involve, among other things:

- increased competition between different financial sectors with the progressive blurring of the traditional frontiers between financial services as banks move into areas previously reserved to insurers - often setting up their own insurance operations;

- increased competition between primary insurers stimulated, inter alia, by the abolition of the remaining market rating agreements (tariffs);

- internationalisation of service activities with the growth of transfrontier trade and transfrontier mergers and acquisitions;

- increased deregulation of the service industries which raises delicate questions about the accountability of insurers especially in liability insurance which has a particular social dimension as a means of compensating third party victims of industrial accidents.

Second, the act considerably enlarged the scope for "qualified majority" voting in the Council of Ministers on matters concerning the "establishment and the functioning of the common market" (art. 18 of the act and art. $8 \mathrm{a}$ and 100 a of the treaty). Art. 100a removes the right of veto from any one member state. Unanimity is now required in only three areas connected with the establishment and functioning of the common market: 
- fiscal provisions;

- free movement of persons;

- rights and interests of employed persons (art. 100a. 2).

\subsection{Competition and consumer protection}

The founding treaties established the primacy of community law in areas of community competence. The Single European Act strengthened community competence in matters affecting consumer and environmental protection (art. 25 of the act and art. 130r $-130 \mathrm{t}$ of the treaty). Community action in these areas is motivated by two main considerations:

- the need to eliminate possible distortions of competition within the Communities due to differences between member states on the rules of liability;

- the wish to improve protection at the community level in the light of events such as the Thalidomide tragedy or the Seveso and Basel pollution disasters.

The Single European Act requires the European Commission to take "as a base a high level of protection" in its proposals concerning "health, safety, environmental protection and consumer protection" (art. 18 of the act and 100a. 3 of the treaty). Increasingly, the future development of public and private law in these areas will be influenced by decisions of the Court of Justice in Luxembourg. In certain circumstances, rulings by the Court suggest environmental and consumer protection can take priority over competition considerations.

Community law takes precedence over national law in matters of community competence. The scope of community law can be expected to broaden as the European Communities continue to develop towards fuller European integration. Developments in the European Communities will influence, in turn, the development of civil liability in other European countries - both east and west - which tend to follow ideas previously worked out in Brussels, e.g. on product liability reform.

In this sense, the Single European Market will affect not only the twelve member states but also the wider Europe beyond - European from the Atlantic to the Urals. And this, in turn, will affect both the availability and affordability of liability insurance cover throughout Europe.

\subsection{Public and private law}

The law of liability in the European Communities is a patchwork of no less than thirteen separate and sometimes competing national jurisdictions with important state or provincial jurisdictions in federal states like the Federal Republic of Germany and, increasingly, Belgium.

Liability in member states is governed by:

- private law (civil law or common law);

- public law (administrative and criminal law).

Public law covers the power of government not only to regulate consumer and environmental protection but also to impose penalties for breaches of regulations. Private law governs, in particular, relationships between citizen (legal persons).

Cases are usually brought in the administrative or criminal courts by the public authorities (under public law) and in the civil courts by employees, customers, consumers or other 
third parties (under private law). And this without prejudice to the right of the latter to bring private prosecutions in the criminal courts.

Liability under administrative or criminal law usually depends on the effective enforcement of regulations by the public authorities. Only too frequently, however, effective enforcement is hampered by lack of funds and lack of personnel.

Fines and penalties under public law are not covered by civil liability insurance. However, civil liability arising from a breach of regulations is, in principle, insurable under the civil liability policy. Conformity with regulations in force at the time of the occurrence of the event giving rise to damage may be no defence against civil liability at some future date. In some countries recourse by the social security organisation against the negligent employer in case of industrial injury will be covered under the civil liability policy.

\subsection{Access to justice}

Liability under civil law depends on the ability of victims to seek redress before the courts: the civil justice system in western Europe is rightly criticised by many lawyers today for not being particularly well-suited to dealing with liability issues. The litigation process is lengthy and costly. Many victims lack the economic resources necessary to enable them to pursue claims through the courts over a period of ten years or more only to risk losing on final appeal.

There is general agreement on the need to reform the civil law. Traditionally, civil liability in western Europe has been based on the notion of fault ("culpa") with a presumption in favour of the defendant (defender). Reversal of the burden of proof has frequently done little to help the majority of victims. In an age of increasingly sophisticated technological development the cards are still stacked in favour of the defendant:

- the defendant (defender) holds all the aces - he has his own intimate knowledge of his own processes and procedures; he has the backing of his own specialist lawyers and his own specialist staff; he has, to quote an old advertisement, the strength of the insurance companies around him;

- the plaintiff (pursuer), however, has a very poor hand - he has his own often imperfect knowledge of the law; he is faced, in many countries, with a presumption in favour of the defendant; he faces long years of litigation ahead; he usually lacks the financial resources necessary to take on a well-equipped, well-armed opponent.

Liability independent of the fault of the wrongdoer or, in legal shorthand, "strict liability" is an attempt to shift the balance in favour of victims of:

- defective products (product liability directive of 25 July 1985-85/374/EEC);

- environmental damage (draft waste liability directive of 15 September 1989 COM(89) 282 final - SYN 217);

- services (draft services directive - COM(90) 482 final - SYN 308).

Strict liability will not, in itself, facilitate access to the courts. Greater use of legal expenses insurance but also contingent fees ("the poor man's door to justice"), class actions, de facto strict liability (based on a quasi-irrebuttable presumption of liability) - these are some of the developments which could be expected to ease the lot of the plaintiff over the next few years. Such developments will inevitably introduce further distortions between 
member states. Forum shopping will be encouraged. Lawyers will find themselves working overtime.

Litigation consciousness is growing. Community policies on consumer and environmental protection are making more citizens more aware of their rights of redress - and more aware of how to exercise those rights. Meanwhile, the European Commission has targeted 1991 for proposals on improved access to justice (see European Commission, Three Year Action Plan, 1990-1992).

\subsection{Liability independent of fault}

American influence on European liability reform has been exaggerated out of all proportion. Europe is not America and America is not Europe. Strict liability is not an American import imposed on an unwilling Europe. Its origins are essentially European. Its roots lie firmly in Europe and common European experience over the last hundred years or more.

This is important. Not least because so many people are haunted by the spectre of feehungry American lawyers descending in droves on the shores of the Old World. If anything, we are seeing in Europe and America what we might call parallel - but not necessarily identical - developments. We see a common awareness of common problems but we also see solutions which are the product of different traditions adapted to the different socioeconomic, cultural and legal conditions in the two continents.

French civil law, in particular, has played a key role in shaping community thinking on consumer and environmental law - especially in the early years of the "Six" before the enlargement of the European Communities in the seventies and eighties. Over the years the French courts have progressively blurred the traditional distinction between:

- contractual liability and

- extra-contractual liability.

Beginning with a benchmark decision of 16 June 1896, the French courts gradually developed a doctrine of quasi-irrebuttable presumption of liability (based on art. 1384 of the Civil Code). Liability is strictly objective ("the damage") rather than subjective ("the behaviour of the author"). Rebuttal is severely restricted.

Jurisprudence in France has been reflected - to a greater or lesser extent - in jurisprudence in countries in the Napoleonic tradition, e.g. in Belgium. Liability independent of the fault of the wrongdoer is to be seen as a major shift in favour of victims of defective products or services or environmental damage. The victim is merely required to demonstrate the causal link between the damage and the wrongdoer for liability to be established. The wrongdoer is civilly liable even though he may have exercised the greatest possible care. The duty of care (beloved of Anglo-Saxon lawyers) becomes an irrelevance under civil law - but not necessarily under administrative or criminal law.

The civil law tradition predominates in the developing law and jurisprudence of the European Communities. The majority of judges in the European Court of Justice in Luxembourg are trained in the civil law tradition. Civil law influence on common law countries like England and Ireland cannot fail to grow as the member states of the European Communities move beyond 1992. 
Increasingly, the future development of both public and private law in member states will be influenced by decisions of the European Court. Rulings by the European Court suggest consumer and environmental protection can, in certain circumstances, take priority over competition considerations.

Community action on consumer and environmental issues makes good sense. Both are international problems. Both are part of the same package of legal protection which is essential to the "establishment and functioning of the common market" (art. 100) where, as we said earlier, the Commission is required to take "a high level of protection" as a base in proposals concerning "health, safety, environmental protection and consumer protection" (art. 100a.3).

The product liability directive of 1985 was only a first step. The draft directives on the liability of producers of industrial waste and on suppliers of services are logical extensions of the consumer and environmental protection already provided under the product liability directive.

\section{Analysis of practical outcomes}

\subsection{Overview of the services directive}

The draft directive on services liability - like the products and waste directives - is predicated on what we might call the ongoing availability and affordability of liability insurance. The product liability directive is already in effect in member states. The waste and services directives are still on the table for discussion.

The products and waste directives cover most industrial and commercial and craft activities (cf. art. 60, Treaty of Rome). The services directive seeks to pick up professional and other activities not covered by the first two.

Liability of the suppliers of services is part of the legal protection package which is essential to the smooth operation of the internal market. Hence the current proposals under art. $100 \mathrm{a}$.

The products and waste directives are based on liability independent of the fault of the author (presumption of liability). They eliminate the notion of fault. The services directive reintroduces the notion of the fault. Liability is based on the fault of the supplier with reversal of the burden of proof (presumption of fault).

There is, in our view, an important difference between presumption of liability and presumption of fault. Presumption of liability reduces the scope for dispute between rival lawyers. Presumption of fault increases it.

This difference is recognised by the Commission which says, in its explanatory memorandum, that it decided to revert to fault in the services directive because :

- certain interest groups had "misgivings" about a directive which provides for liability independent of fault;

- most national legal systems - except in certain specific areas - are still based on "the principle that the supplier is at fault" even though this principle is frequently subject to broad interpretations;

- there is "a certain reluctance to change this situation too radically at present". 
Fault liability with the burden of proof on the plaintiff is the source of much pain to litigants - and much wealth to lawyers (as we know from the United States - surely the most litigation-conscious country in the world). A reversal of the burden of proof is a step in the right direction - but it is only a very hesitant first step. It is unfortunate that the European Commission has felt unable to introduce a system of services liability which would dovetail with the system of product liability under the 1985 directive which - with all its imperfections - clearly enunciates the principle of liability independent of fault.

Presumption of liability under the products directive frees monies which insurers are otherwise obliged to set aside as claims reserves. It also reduces legal costs which represent one of the most important (and most negative) features of the American justice system.

Presumption of fault can be equated with a presumption of a breach of a professional duty of care. This opens the door to a state-of-the-art defence which weakens the position of victims. Such a defence is incompatible with a presumption of liability independent of the fault of the wrongdoer, e.g. in the product liability directive.

The Commission believes it would be unwise "to change this situation too radically at present" but it does not rule out such a radical change in due course. Indeed, such change could be brought about by the European Court of Justice on the ground of conflict between the two liability regimes which, as the Commission admits, will inevitably overlaps from time to time. In the final analysis it will only produce confusion where plaintiffs can rely in some cases on presumption of liability (liability independent of fault, e.g. product liability) and in others on presumption of fault (fault liability with reversal of the burden of proof).

\subsection{Contents of the directive}

The services directive focusses liability on the supplier (and persons assimilated to the supplier). Liability is based on a presumption of the fault of the supplier "in performance of the service" subject only to proof of causality by the victim.

Liability remains subjective (emphasis on the behaviour of the author) rather than objective (emphasis on damage to persons or property). Liability is joint and sevreal liability "in solidum".

\subsection{Damage covered}

The directive covers "damage to the health and physical integrity of persons or the physical integrity of movable or immovable property" (art. 1.1). Damage to persons means death and bodily injury including industrial accidents (art. 4). Damage to property covers movable or immovable property. Property used exclusively or mainly for professional purposes is excluded (art. 4.b).

Pure financial loss, pain and suffering ("pretium doloris") and other "non-material" damage are left to national law.

\subsection{Services covered}

The directive covers "any transaction carried out on a commercial basis or by way of a public service" (art. 2) other than:

- designers and manufacturers of "movable property";

- transfer of rights in rem or intellectual property rights; 
- services "intended to maintain public safety";

- "package travel";

- "waste services".

Liability for "damage covered by liability arrangements governed by international agreements", e. g. nuclear or transport liability, is excluded.

Bad advice on financial or insurance services would appear to be covered by the directive.

\subsection{Basis of liability}

Liability is subjective ("the damage") rather than strictly objective ("the behaviour of the author"). The supplier is liable for "damage... caused by a fault commited by him in the performance of the service" (art. 1.1). Fault is, therefore, strictly relevant to determining liability. The supplier must prove the "absence of fault" (art. 1.2).

Liability is joint and several - liability "in solidum" (art. 8). Rights of recourse under national law are expressly preserved (art. 8.1).

\subsection{Basis of fault}

Fault is equated with reasonable expectations of safety.

Presumption depends on "the behaviour of the supplier of the service who, in normal and reasonably foreseeable conditions, shall ensure the safety which may reasonably be expected" (art. 1.3).

There is no presumption where "a better service existed or might have existed at the moment of performance or subsequently" (art. 1.4).

\subsection{Potentially liable parties}

The directive focusses liability on the "supplier of services" (art. 3). The "supplier" includes:

- any natural or legal person who supplies a service "on a commercial basis or by way of a public service and in an independent manner, whether or not in return for payment" (art. 2);

- any person who uses the services of a "representative or other legally independent intermediary" (art. 3.2);

- any franchisor, master franchisor or franchisee within the meaning of Commission Regulation 4087/88 of 30 November 1988 (art. 8.2) unless he can show that he did not supply the product;

- any "person carrying out the service" on behalf of a third country supplier who is not established in the European Communities (art. 3.3).

Many services available within the Communities originate in third countries, e. g. companies domiciled in the United States or Japan. Competition and consumer protection considerations require services originating in third countries to be subject to the rules applying to services originating in the European Communities.

The directive cannot touch third country suppliers but it can touch persons (agents or local companies) "carrying out the service" within the Communities. Hence the directive 
assimilates importers of services from third countries to community suppliers. In this sense, community importers have the same rights and obligations as community suppliers.

The position of victims is clearly made easier where they only have to address themselves to a single person or to a limited number of well-defined persons. In this sense, liability of the suppliers of services parallels solutions adopted in the product and waste liability directives.

\subsection{Causality}

The supplier is liable for damage caused by a fault on his part subject only to proof by the victim of :

- the damage and

- causal relationship between the performance of the service and the damage (art. 5).

The supplier must be identified. No provision is made for damage caused by an unidentified supplier.

\subsection{Limitation of liability}

The supplier may not limit or exclude by contract his liability under the directive (art. 7).

Liability for damage to persons and property is unlimited in amount. Here the directive follows the civil liability tradition in most countries of western Europe in rejecting any financial limitation of liability. This is generally welcomed by insurers. It is important, however, to keep in mind the clear distinction between:

- limits of liability (legal limits) and

- limits of cover (policy limits or limits of indemnity).

\subsection{Defences}

Liability may be avoided or reduced where the supplier proves, e.g.

- that he provided "the safety which may reasonably be expected" (cf. art. 1.3);

- that the damage was caused jointly by his fault and "the fault of the injured person or a person for whom the injured person is responsible" (art. 6.2);

- that the damage was caused by force majeure ("damnum fatale") or compliance with mandatory regulations.

Liability may not be reduced where damage is caused jointly by the fault of the supplier and the intervention of a third party (art. 6.1).

\subsection{Prescription and extinction of liability}

Proceeding for the recovery of damages must begin within:

- ten years (in case of services relating to the design or construction of immovable property) or

- three years (in case of other services)

of the date on which the victim became aware (or should reasonably have become aware) of the damage, the service and the identify of the supplier (art. 10.1). 
Liability under the directive is extinguished:

- twenty years (in case of services relating to the design or construction of immovable property) or

- five years (in case of other services)

from the date on which the service which caused the damage was supplied - unless the victim has already begun legal, administrative or arbitration proceedings against the supplier (art. 9).

\subsection{Implementation}

The directive must be brought into effect by 31 December 1992. The necessary "laws, regulations and administrative provisions" must be adopted by member states by this date (art. 12.1).

\subsection{Retroactive application}

There is no retroactive application. Liability only applies to damage caused by services provided after 31 December 1992 (art. 11; cf. art. 12.1).

\subsection{Options}

The directive does not provide member states with any special options. This reduces the scope for distortion between member states.

\subsection{Absence of compensation}

The directive makes no provision for compensation of damage where the supplier:

- cannot be identified or

- is unable to pay full compensation for damage sustained.

Both issues leave the door open to compulsory insurance of compensation funds.

\section{Consequences for insurance}

\subsection{Problems of insurance}

Insurance is not mentioned in the directive. The European Commission has long accepted the insurance industry view that insurance cover will continue to be available in member states at a price which suppliers can afford - and can easily pass on to their clients or customers.

The purpose of liability insurance is to pay the losses of third parties of which the insured is liable under civil law. It covers his contractual and extra-contractual legal liability. It does not normally cover extra-legal liabilities assumed under contract.

Policy limits under a voluntary system will continue to be freely negotiated on the basis of the readiness of the insurer to provide the cover and the willingness of the insurance buyer to pay the premium.

Liability insurance cover in the field covered by the services directive is normally provided by :

- general liability policies;

- professional liability policies. 
General liability policies cover activities of an industrial or commercial character as well as the activities of craftsmen or artisans. Professional liability policies are usually limited to particular spheres of activity such as architects and surveyors, architects, doctors, lawyers or construction engineers.

Currently, the market for professional liability insurance is fairly small. Most general insurers tend to follow recognised market leaders on a coinsurance basis. Business is often written by specialist insurers, e.g. Lloyd's or specialist mutuals.

Claims are usually processed in one of three ways:

a) act committed basis - claims are settled under the policy in force at the time act giving rise to the damage was committed, e.g. design or production stage. Act committed is often used in continental professional liability policies and in Swiss general liability policies.

b) loss occurrence basis - claims are settled under the policy in force at the time the damage occurred, e.g. first exposure or first manifestation or discovery of damage. Loss occurrence is traditionally used in most general liability policies.

c) claims made basis - claims are settled under the policy in force at the time the claim is made or notified to the insurer. The claims made basis is only used to any extent in special covers, e.g. professional indemnity in the United Kingdom.

Traditionally, liability insurers have limited cover (under the act committed and loss occurrence bases) to events which are sudden, unintended and unexpected. Insurers have argued that losses which are reasonably foreseeable and, therefore, avoidable are not fortuitous and, as such, are not insurable.

In other words, policies usually exclude events which are neither sudden nor accidental. "Sudden" and "accidental" have become virtually synonymous. This poses problems where events occur over an extended period but may not be known until some considerable time later, e.g. latent injuries. Events do not have to be sudden in order to be accidental (in the sense of unintended and unexpected). Hence moves in some markets to replace "sudden" and "accidental" with "fortuitous" which gets round the problem of deciding when events stop being sudden. Other markets are interpreting occurrence as first manifestation or first discovery which brings it closer to the date of claim.

Insurers, nevertheless remain wary of "gradual" events where loss has occured but remain unknown, unknowable or undetectable over many years.

Claims made has not proved popular with insurance buyers or with the general public who see it as being far too "insurer-friendly". General liability insurers are no longer pushing for claims made with the enthusiasm they had previously shown in some markets.

Although the directive makes no mention of insurance there is no doubt that the decision to rely upon voluntary arrangements is predicated on the ongoing availability and affordability of liability insurance. Insurers and insureds are understandably concerned about possible increases in insurance costs linked directly to the implementation of the services directive in national law. And there is no doubt that insurance costs will go up at least in the short term. 
The Commission assures us in its explanatory memorandum:

"it held discussions with insurance experts and studies were conducted. The studies made it clear that only a rclatively small increase in insurance premiums would be required to cover the introduction of an objective liability system (sic) and that general adoption of the principal of reversal of the burden of proof would not entail excessive additional costs. ${ }^{1}$

Even if additional premiums, were charged, the extra costs would no doubt be added to the prices charged by suppliers for their services, and consumers are prepared to pay this price. The present position of persons suffering damages would thus be clarified without costing the suppliers of services an excessive amount of money. Moreover, suppliers would then all be in the same position and would enjoy the advantages of operating under the same conditions, which is not the case at present" (para. 1.6).

We agree broadly with what is said here but we think the reintroduction of fault in the revised text of the directive cannot fail to complicate claims settlement and impact adversely on insurance costs - which would not be the case with liability independent of fault.

The purpose of the directive is to spread the net of compensation wider - to pay claims where previously they would have remained unpaid. And even those claims which are subsequently declined under the new system of liability, e. g. because of difficulties of establishing the causal link, will have to be defended. Loss prevention and loss control costs, including legal costs, will continue to play a major role in any defense strategy in the future.

Insurance costs will continue to be passed on to the customer or the client - and will continue to be measured in cents rather than écus. The fact remains, however, that it is absolutely impossible to make any forecast today of the likely increase in insurance costs when neither the final form nor the date of implementation of the directive are known. Attempts to pressure insurers into doing so could backfire with insurers feeling themselves obliged to err on the side of pessimism.

At present, the majority of claims are settled out of court. This is true in all states. This will probably continue in the future under the directive - provided the intentions of the directive are clearly understood. Uncertainty can only result in increased costs of litigation and increased costs of insurance. This remains a distinct possibility with the product liability directives where various options open to member states risk creating new distortions of competition and encouraging forum shopping.

Many professions, including hospital and medical services, accountants, construction engineers, architects and surveyors, are deeply concerned about "the number of claims made against them, extensions of their liability and increased insurance costs... Whether this is mainly their own fault (sic) because of falling standards, the absence of risk management

1 The directive was drafted in French. The translation leaves much to be desired, e.g. the use in English of the expression "objective liability" which is a direct but far from accurate translation of "responsabilité objective".

For reasons explained elsewhere objective liability and fault liability - even with reversal of the burden of proof - do not go together. 
procedures or inadequate staff training or a reflection of today's litigious times are matters to be considered" (Post Magazine, 23 February 1989). One reaction to these developments is the growth of specialist captives or mutuals, e.g. for accountants or solicitors.

None of this will necessarily satisfy those who are concerned with cases where the potentially liable party is uninsured, insolvent or, quite simply, is no longer in business. If liability insurance remains voluntary what guarantee will there be that victims will, indeed, be compensated?

\subsection{Compulsory insurance}

The European Commission does not believe that compulsory insurance is necessary. Is it right to do so?

Consumer protection requires an effective regulatory and compensatory framework. But what happens where there are serious doubts about the availability and affordability of liability insurance cover, e.g. in areas involving medical malpractice? Insurance cover is far too important to be left to the vagaries of the free market and the interplay of supply and demand.

The existence of liability insurance cover is (or should be) the best guarantee of compensation subject only to proof of causality. Hence pressure for compulsory insurance.

The compulsory insurance option should be considered here under several heads:

- coverage of exceptionally hazardous risks;

- coverage of large risks which require exceptionally large capacity;

- coverage of risks which are insufficiently well-known;

- coverage of risks which are insufficiently numerous to allow the effective operation of the law of large numbers.

Professional liability insurance clearly fits one or more of these categories. Many risks are particularly hazardous. Many risks do require exceptional capacity. Many risks - especially latent risks - are insufficiently well-known...

Compulsory liability insurance would:

- combat the effects of selection against the insurer by providing for the spread of risk which is essential to sound underwriting;

- respond to the modern shift of emphasis from the protection of assets (which hitherto bas been the primary objective of corporate risk management) towards the compensation of victims both speedily and adequately, e. g. by introducing liability independent of fault throughout the European Communitites;

- respect the notion of individual liability. It accords with liability focussed on the supplier (or persons assimilated to the supplier). Recourse to collective responsibility (e.g. back-up compensation fund) is restricted to specified cases, e.g. where the supplier cannot be identified or cannot compensate damage.

In principle, insurers are always opposed to compulsory insurance. In practice, they seem perfectly capable of living with it. They are able, for example,

- to accept compulsory liability insurance under the Convention on the Carriage of Dangerous Goods (CRTD) of the United Nations Economic Commission for Europe (UNECE); 
- to operate compulsory nuclear insurance and compulsory motor insurance (throughout western Europe), compulsory employers' liability insurance (United Kingdom), compulsory pollution insurance (Belgium), compulsory workers' compensation insurancc (Belgium, Portugal), compulsory pharmaceutical insurancc (Germany), compulsory liability insurance of numerous professional and business activities (France)...

France leads the European Communities with compulsory liability insurance provisions for some eighty activities including:

- legal and parafiscal professions, e.g. advocates and notaries, accountants and auditors, tax consultants;

- construction and real estatc professions, e. g. architects and estate agents, building contractors and others;

- medical and paramedical professions, c.g. doctors, pharmacists and midwives;

- other activities, e.g. driving school instructors, travel agents, physical education and sports centres.

Insurers often claim compulsory insurance cannot be enforced. But is this really true? Think of the examples mentioned above. In the United Kingdom, for instance, every business establishment is obliged to display a certificate of employers' liability insurance on the premises. Not every firm will necessarily respect this obligation. But this is no reason to abandon compulsory insurance which serves the public interest.

Compulsory insurance can be written on an unlimited indemnity basis, e.g. employers' liability in the United Kingdom. The idea of unlimited cover dates, however, from a time when it was quite simply impossible to envisage the sort of catastrophic loss which could jeopardise the stability not only of individual insurers but also of whole insurance markets.

Policy limits are now considered essential to the quantification and qualification of the liability risk - particularly in areas of catastrophic exposure which are characterised by low frequency and high severity of loss. Compulsory insurance will still be subject to policy limits even where legal liability is unlimited.

Compensation provided by an authorised insurer rather than the potential wrongdoer is, moreover, a guarantee of payment to victims subject only to proof of causality. Above all, the nuclear model teaches us that it is better to set up an effective compensation mechanism before rather than after something has gone wrong.

\subsection{Problems of regulation and self-regulation of services}

The choice, in bricf, lics between:

- regulation by government (the colbertist option);

- self-regulation by individual trades and professions (the thatcherite option).

Self-regulation supposes the ability and the readiness of individual service sectors to keep their own houses in order. This is one of the objects of deregulation. Exercise of a particular activity may require membership of a trade or professional institute which, in turn, may require liability insurance to be taken out - either individually or collectively. This is not compulsory insurance in the traditional sense.

Regulation by government recognises possible conflicts of interest where members of a service industry arc expected to police themselves. City scandals incvitably raise doubts 
about the ability of professionals to keep their own houses in order. We suspect the thatcherite option has been tried and found wanting. We may yet find it necessary to revert to the colbertist option.

On this count, external regulation is both necessary and desirable. This, in the colbertist view, is the role of the state. The state licences the members of a particular trade or profession subject, perhaps, to evidence of insurance in accordance with statutory requirements.

\section{Prospects for the future}

Services liability is an important segment in the liability circle which the Commission is determined to close. Arguments in favour of a uniform regime of civil liability within the European Communities are overwhelming. Lack of uniformity is a "bad thing". It is contrary to the "spirit" of the treaties. It leaves a major gap in liability protection at the community level. It encourages forum shopping.

In due course, the abolition of the remaining internal barriers to trade after 1992 will necessitate the approximation of legal standards of proof - including causality.

In the short term, media attention surrounding the introduction of liability based upon a presumption of fault of the supplier can be expected to lead to an increase in the number of claims - not in the number of cases of damage. This, of course, is the object of community action - to make it easier for victims to receive compensation where previously this would have been difficult, if not impossible. Litigation consciousness will grow. But this, surely, is the (not altogether undesirable) price of social progress.

Inevitably, this will cost money, e.g. in increased defence costs. And the money will have to be found somewhere, e.g. in increased insurance premiums which suppliers of services will seek to pass on to their customers or clients in the form of higher prices. But things must be kept in perspective. Insurance costs (and the effect of any increases directly linked to the directive) will continue to be negligible compared to other business costs, e.g. labour, raw materials, premises, advertising, etc.

Good directives can be expected to speed up the payment of compensation something which is beneficial to all concerned including insurers. Poor directives merely spread confusion. And confusion in insurance terms costs money, e. g. it encourages forum shopping.

Hitherto, suppliers of services and their insurers have been able to rely on a philosophy which tended to favour the wrongdoer with the plaintiff only able to recover damages where he has been able to show fault of the defendant to the satisfaction of the court. This will no longer be possible - provided, of course, improved legal protection is matched by improved access to the courts. And this is a matter for the European Communities rather than individual member states.

In the long term, we believe a presumption of fault of the supplier must give way to a quasi-irrebuttable presumption of liability. And this because we have every reason to suppose that the elimination of disputes about fault cannot fail to have a beneficial effect on legal and insurance costs:

- by focussing liability on the supplier of the service (or persons assimilated to the supplier) and 
- by removing or, at least, reducing doubts about the identity of the supplier;

- by encouraging greater attention to loss prevention and loss control since a properlystructured programme of risk management will be the only true defence against loss and hence against liability.

Consumer protection requires emphasis to be placed on the rapid payment of compensation of victims. One way of doing this would be to generalise throughout the European Communities the right which already exists in France of direct action of the victim against the insurer - whether or not liability insurance is compulsory. Let victims be paid first and let insurers and insureds argue about it later!

In other countries, e.g. Belgium, this right only exists in the case of compulsory insurances. Most continental insurers would be prepared to accept direct action under a compulsory insurance scheme, e.g. UNECE (UNIDROIT) convention on the carriage of dangerous goods. The United Kingdom government and insurance market are wholly opposed to direct action.

\section{Conclusion}

One industry representative recently described the decision to abandon presumption of liability in favour of presumption of fault as "undoubtedly an improvement on the first draft...". We cannot accept this view which we think is contrary to the interests of insurers and insurance users and, above all, those who remain who remain unknown until something has gone wrong - the third party victims.

People should be protected against damage to their persons or their property. It is no longer reasonable to expect them to have to carry the burden of proving the fault of the wrongdoer.

There is nothing new about a presumption of liability, still less about a presumption of fault. And there is nothing new about insurers covering such liabilities. Insurers, of course, will still have to defend claims - especially those claims which are subsequently declined because the causal link between damage, service and supplier cannot be proved.

Liability insurers are (or should be) interested in settling claims quickly. The longer is takes to settle a claim the longer reserves have to be set aside to meet eventual payment.

This can be problematic - particularly in an inflationary environment.

A number of problems remain outstanding. These include:

- unidentified suppliers where market share liability is unlikely to be adopted;

- access to justice where community action is targeted for 1991;

- direct effect of directives where failure to bring community liability measures into effect on the same date introduces a new note of distortion between member states;

- redefinition of furtuity to emphasise the restriction of coverage to unforeseen and unintended events - irrespective of whether such events occur suddenly or gradually.

Should professional liability insurances continue to be subject to the vagaries of the free market? Will conventional methods prove sufficient for the future? Or must insurers look to new ways of providing cover, e. g. captives, mutual funds, accident insurance or other compensation schemes.

Will compulsory insurers prove inevitable in one or more service sectors? And if insurance is made compulsory what about those who fail to take out insurance or have gone out of business? 


\section{B1BLIOGRAPHY}

BROUSSEAU, S., et al., La preuve du dommage corporel, L'Argus, Paris, 1981.

CHABAS, F., Le droit des accidents de la circulation après la réforme du 5 juillet 1985, Gazette du Palais, Paris, 1985.

COCRAL, F., Les responsabilités civiles diverses, L'Assurance française, Paris, 1980.

de CRAYENCOUR, J.-P., The Professions in the European Community, Office for Official Publications of the European Communities, Luxembourg, 1981.

FINDLATER, J., ed., Consumer Policy, 1rish Centre for European Law, Trinity College, Dublin, 1991.

GHESTIN, J., Sécurité des consommateurs et responsabilité du fait des produits défectueux, Librairie Générale de droit et de jurisprudence, Paris, 1987.

HARTLEY, T., The Foundations of European Community Law, Second Edition, Clarendon, Oxford, 1988.

JONAS, H., The Imperative of Responsibility, In Search of an Ethics for the Technological Age, University of Chicago, 1984

LAMBERT-FAlVRE, Y., Droit des assurances, Sixième édition, Dalloz, Paris, 1988.

MARShALL, E., General Principles of Scots Law, Fourth Edition, W. Green \& Son, Edinburgh, 1982.

MATHIJSEN, P.S. R. F., A Guide to European Community Law, Fourth Edition, Sweet \& Maxwell, London, 1985.

N1CHOLAS, B., French Law of Contract, Butterworths, London, 1982.

RAWLINSON, W. and CORNWELL-KELLY, M., European Community Law, Waterlow, 1990.

RENODON-DELUBR1A, C. and ROUSSEL, J., Les Assurances obligatoires, L'Argus, Paris, 1984.

STEFAN1, G., LEVASSEUR, G. and BOULOC, B., Droit pénal général, Treizième édition, Dalloz, Paris, 1987.

STEWART, W., The Scots Law of Delict, Green \& Son, Edinburgh, 1989.

WElLL, A. and TERRÉ, F., Droit civil, Quatrième édition, Dalloz, Paris 1986.

Belgisch Burgerlijk Wetboek - Code Civil Belge, Maraboe-Marabout, Brussels, 1986.

Code Civil, Quatre-vingt cinquième édition, Dalloz, Paris, 1985.

Competition Law in the EEC and in the ECSC, Office for Official Publications of the European Communities, Luxembourg, 1981.

General Liability lnsurance and the Large Insurance Buyer, Comité Européen des Assurances, Paris, 1988.

Réparation des dommages catastrophiques, Université Catholique de Louvain, Louvain-la-Neuve, 1988.

Treaties establishing the European Communities, abridged edition, Office for Official Publications of the European Communities, Luxembourg, 1987. 